\title{
Operando XANES study of simulated transient cycles on a Pd-only three-way catalyst
}

Ye Lu, ${ }^{1}$ Santhosh Kumar Matam, ${ }^{1}$ Gian Luca Chiarello, ${ }^{1}$ Panayotis Dimopoulos Eggenschwiler, ${ }^{2}$ Christian Bach, ${ }^{2}$ Martin Weilenmann, ${ }^{2}$ Alex Spiteri, ${ }^{2}$ Anke Weidenkaff, ${ }^{1}$ Davide Ferri, ${ }^{1,3 *}$

${ }^{1}$ Empa, Swiss Federal Laboratories for Materials Science and Technology, Lab. for Solid State Chemistry and Catalysis, Ueberlandstrasse 129, CH-8600 Dübendorf, Switzerland

2 Empa, Swiss Federal Laboratories for Materials Science and Technology, Internal Combustion Engines Lab., Ueberlandstrasse 129, CH-8600 Dübendorf, Switzerland

${ }^{3}$ Paul Scherrer Institute, CH-5232 Villigen PSI, Switzerland

* Corresponding author. Phone:+41 56310 2781; e-mail: davide.ferri@psi.ch 


\begin{abstract}
A model Pd-only three-way catalyst has been subjected to simulated driving conditions of natural gas and gasoline operation in an operando reactor cell for X-ray absorption spectroscopy that included alternated, but longer than real oscillations, rich and lean periods and a high temperature surge $\left(850-900^{\circ} \mathrm{C}\right)$. The XANES spectra indicated that metallic palladium is observed in the whole temperature range investigated (up to $900^{\circ} \mathrm{C}$ ) and irrespective of the air/fuel ratio. In both natural gas and gasoline cycles, the XANES data show that the $\mathrm{PdO}$ reduced in the rich periods cannot be restored in the lean periods. With this background, activity for methane abatement in the high temperature regime is greatly affected by the oxidation state of palladium rather than by the change of air/fuel ratio. In the case of propene oxidation, while $\mathrm{Pd}$ also remains predominantly in the reduced state, activity is dictated by the oxygen concentration in the feedstock. Comparison between the two hydrocarbons demonstrates that the oxidation state of $\mathrm{Pd}$ may be responsible for observed methane emissions under realistic operating circumstances. Moreover, the experiments demonstrate that reduced $\mathrm{Pd}$ may be continuously present during operation in agreement with observations on real catalytic converters. Although this may be the average oxidation state of $\mathrm{Pd}$, more advanced probes are certainly necessary to capture variations of oxidation state under the fast oscillatory conditions needed to imitate real operation.
\end{abstract}

Keywords: natural gas; gasoline; three-way catalyst; Palladium; methane oxidation 


\section{Introduction}

Natural gas receives increasing public awareness as an alternative to gasoline and diesel fuels. The advantages of natural gas ( $>90 \%$ methane, $\left.\mathrm{CH}_{4}\right)$ are numerous, including the lowest $\mathrm{CO}_{2}$ emission per unit energy and the low toxic emissions. However, $\mathrm{CH}_{4}$ slip from the engine needs to be treated catalytically because of the large global warming potential of $\mathrm{CH}_{4}$. Precious metals, e.g. $\mathrm{Pd}$ and $\mathrm{Pt}$, are the most active for $\mathrm{CH}_{4}$ oxidation [1]. The oxidation activity of palladium is greatly hampered at temperatures higher than $700^{\circ} \mathrm{C}$ because of the spontaneous reduction of active $\mathrm{PdO}$ to metallic $\mathrm{Pd}[2,3]$. Such temperatures are periodically attained upon motorway operation as a consequence of increased catalyst load. For close coupled catalytic converters, high temperatures belong to regular operating conditions.

Under realistic driving conditions of stoichiometric engines, $\mathrm{CH}_{4}$ slip is often observed during transient engine operation at higher speed and temperature than average operation (Figure 1). Total hydrocarbon (THC) emissions are also higher for natural gas operation than for gasoline operation [4]. Additionally, it is known that $\mathrm{CH}_{4}$ conversion in catalytic converters also decreases for fuel lean engine operation $(\lambda>1)$, thus reflecting $\mathrm{NO}_{\mathrm{x}}$ emissions, that is contrary to the typical behavior of higher hydrocarbons [5-7]. The difference with respect to hydrocarbon emissions between natural gas and gasoline operation could be related to the state of the precious metal(s), among other possible effects that are difficult to disentangle $[6,8]$. The state of precious metals of three-way catalyst (TWC) formulations has been rarely studied under simulated reaction conditions of $\lambda$ oscillations and in a wide temperature range [9-11]. Recently, time-resolved methods have provided deeper insight into the dynamic behavior of metal nano-particles under 
oscillating conditions close to TWC operation [12-14]. In this respect, X-ray absorption spectroscopy is a powerful tool to elucidate structure-activity relationships of working catalysts [15]. In this work we subjected a model Pd-only three-way catalyst to simulated driving cycles of natural gas and gasoline engines while recording operando XANES spectra in order to correlate catalytic activity for $\mathrm{CH}_{4}$ and propene $\left(\mathrm{C}_{3} \mathrm{H}_{6}\right)$ oxidation under TWC conditions with the oxidation state of palladium. Our discussion is confined to hydrocarbon conversion and will not discuss the effect of other species (e.g. $\left.\mathrm{H}_{2} \mathrm{O}\right)$ and of the complex reaction network and conditions that are involved in TWC operation $[8,16-$ $18]$.

\section{Experimental}

The powder alumina and alumina-ceria-zirconia supported Pd samples (hereafter Pd/A and $\mathrm{Pd} / \mathrm{ACZ}$, respectively) with $1.6 \mathrm{wt} \% \mathrm{Pd}$ were kindly provided by Umicore as model Pd-only three way catalysts. Operando X-ray absorption near edge structure (XANES) spectra were recorded in the transmission mode at the Pd K-edge $\left(\mathrm{E}_{0}=24.35 \mathrm{keV}\right)$ at the beamline X1 of Hasylab (DESY, Hamburg). The electrically heated quartz reactor cell $\left(d_{\mathrm{i}}=20 \mathrm{~mm}\right)$ was connected to a gas-feeding system with mass-flow controllers and was interfaced to a mass spectrometer $[19,20]$. The sample (400 mg, sieved 150-200 $\mu \mathrm{m})$ was firmly placed between two plugs of quartz wool, one end being placed against a quartz frit. The reactor was mounted in the furnace so that the X-ray beam passed axially through the reactor tube and the optical pathlength coincided with the catalyst bed length (ca. $2 \mathrm{~mm}$ ). After pre-treatment at $300^{\circ} \mathrm{C}$ for $30 \mathrm{~min}$ in $5 \mathrm{vol} \% \mathrm{O}_{2} / \mathrm{He}(400 \mathrm{ml} / \mathrm{min})$, the oxidation state of Pd species was monitored under varying conditions of $\lambda=0.97,1.01$ 
and 1.1 and in a wide temperature range $\left(100-900^{\circ} \mathrm{C}\right)$ using a simulated exhaust composition of a stoichiometric natural gas engine (7000 ppm CO, $1300 \mathrm{ppm} \mathrm{CH}_{4}, 1600$ ppm NO, 5012-5396 ppm $\mathrm{O}_{2}$, bal. He; GHSV=76'000 $\mathrm{h}^{-1}$ ). The MS signal for oxygen $(\mathrm{m} / \mathrm{z} 32)$ was used to confirm that the air/fuel ratio effectively changed. High temperature was targeted to simulate the acceleration section of the driving cycle. In the case of a gasoline engine, $150 \mathrm{ppm}_{3} \mathrm{H}_{6}$ were used together with 2650-3025 $\mathrm{ppm} \mathrm{O}_{2} . \mathrm{Pd} / \mathrm{ACZ}$ was also subjected to two consecutive heating-cooling cycles under stoichiometric conditions (7000 ppm CO, 1300 ppm CH 4,1600 ppm NO, 5300 ppm O 2 , bal. He; GHSV= 76’000 h

${ }^{1}$ ) in the temperature range of $100-850^{\circ} \mathrm{C}$, as described elsewhere [21]. XANES spectra were recorded continuously during the heating, dwell and cooling segments. The raw data were analyzed using the WINXAS 3.1 software package [22]. Room tempearture $\mathrm{k}^{3}$ weighted FT-EXAFS data were obtained in the k ranges of 2-16 $\AA^{-1}, 2-13 \AA^{-1}$ and 2-12 $\AA^{-1}$ for the reference Pd foil, fresh $\mathrm{Pd} / \mathrm{ACZ}$ and used $\mathrm{Pd} / \mathrm{ACZ}$, respectively.

Experimental exhaust emission and catalytic conversion efficiency investigations with a Euro-4 natural gas vehicle were performed on a chassis dynamometer using the realworld based driving cycle from the EU project ARTEMIS (Common Artemis Driving Cycle) [23].

\section{Results and discussion}

Figure 2a shows the behavior of the MS signals corresponding to $\mathrm{NO}, \mathrm{CO}\left(\mathrm{N}_{2}\right), \mathrm{CH}_{4}$, $\mathrm{CO}_{2}, \mathrm{H}_{2}, \mathrm{H}_{2} \mathrm{O}$ and $\mathrm{O}_{2}$ when subjecting the $\mathrm{Pd} / \mathrm{ACZ}$ catalyst to a simplified transient cycle for natural gas catalyst operation in the XAS reactor cell. The cycle consisted of heating to $500^{\circ} \mathrm{C}$ under reducing conditions $(\lambda=0.97)$, dwelling at $500^{\circ} \mathrm{C}$, heating to $900^{\circ} \mathrm{C}$ under 
reducing conditions, cooling to $500^{\circ} \mathrm{C}$ under slightly lean conditions $(\lambda=1.01)$ and dwelling at $500^{\circ} \mathrm{C}$. At $500^{\circ} \mathrm{C}$, both prior to heating to $900^{\circ} \mathrm{C}$ and after cooling, $\lambda$ was varied between 0.97 and 1.01, which is a common $\lambda$-variation for stoichiometric engine operation. At $500^{\circ} \mathrm{C}$ at the rich end of the stoichiometric $\lambda$-window $(\lambda=0.97), \mathrm{CH}_{4}$ reforming occurs as it is evident from the evolution of hydrogen and $\mathrm{CO}$. That a change of the $\lambda$ value effectively occurs is confirmed by the next switch to the lean end of the stoichiometric $\lambda$-window $(\lambda=1.01)$ that results in the increase of $\mathrm{CH}_{4}$ and $\mathrm{CO}$ conversions and a decrease of $\mathrm{H}_{2}$ concentration, as well as by the reversed switch to $\lambda=$ 0.97. Upon heating to $900^{\circ} \mathrm{C}$ at the rich end $\mathrm{CH}_{4}$ conversion increases; this is mirrored by NO depletion and by an increase of outlet $\mathrm{H}_{2}$ and $\mathrm{CO}$ (signal influenced by possible $\mathrm{N}_{2}$ production) as a result of $\mathrm{CH}_{4}$ reforming. Above $700^{\circ} \mathrm{C}, \mathrm{H}_{2}$ production decreases. The $\mathrm{CH}_{4}$ conversion is almost complete above $700^{\circ} \mathrm{C}$. Upon switching to the lean end at $900^{\circ} \mathrm{C}$, the effect of increased oxygen concentration is evident from the quick drop of both $\mathrm{CO}$ and $\mathrm{H}_{2}$ signals. During cooling, the $\mathrm{CO}$ signal reaches the level obtained at $500^{\circ} \mathrm{C}$ under $\lambda=1.01$ prior to heating. $\mathrm{CH}_{4}$ conversion decreases as well but attains a lower level at $500^{\circ} \mathrm{C}$ than prior to heating under rich conditions indicating less favorable reaction conditions. The last $\lambda$ switch from 1.01 to 0.97 at $500^{\circ} \mathrm{C}$ causes a further decrease of $\mathrm{CH}_{4}$ conversion. It is clear from Figure 2a that the behavior of the NO signal closely follows that of $\mathrm{CH}_{4}$ confirming a close relationship between the abatement of the two pollutants $[8,24]$. This is not the case for $\mathrm{C}_{3} \mathrm{H}_{6}$ (Figure 2b). NO concentration increases in the cooling segment under lean conditions after exposure to high temperature while $\mathrm{C}_{3} \mathrm{H}_{6}$ conversion remains unaltered. 
The operando XANES spectra recorded continuously during this transient cycle show that the state of $\mathrm{Pd}$ in $\mathrm{Pd} / \mathrm{ACZ}$ prior to heating to $500^{\circ} \mathrm{C}$ under $\lambda=0.97$ corresponds to that of a supported PdO catalyst (Figure 3a). While heating, the oxidation state of the catalyst does not change until $300^{\circ} \mathrm{C}$. Reduction occurs suddenly between 300 and $350^{\circ} \mathrm{C}$. The XANES spectrum at $500^{\circ} \mathrm{C}$ is characterized by the typical EXAFS oscillations and is obviously different from that representing the initial state. In the case of simulated gasoline operation, $\mathrm{Pd}$ reduced ca. $50^{\circ} \mathrm{C}$ earlier (Figure $3 \mathrm{~b}$ ). For both hydrocarbons, the variation of the $\lambda$ value from the rich to the lean end does not cause any visible spectral change. There is no tangible evidence that the oxidation state of Pd differs from the reduced one in the whole cycles of Figure 2. Therefore, the catalyst remains predominantly in the reduced state independently from heating-cooling cycle and from $\lambda$ switches. However, the static nature of the data does not allow concluding whether surface re-oxidation occurred upon $\lambda$ switches $[12,13]$. At the end of the experiment of Figure 2, $\lambda=1.1\left(>6200 \mathrm{ppm} \mathrm{O}_{2}\right)$ was provided to the catalyst at $500^{\circ} \mathrm{C}$ to induce further changes. Visible but partial re-oxidation of Pd could be observed (Figure 3a). Only large excess of oxygen $(\lambda>>1.1)$ caused evident changes as demonstrated in Figure $3 b$. The constantly reduced state of $\mathrm{Pd}$ in $\mathrm{Pd} / \mathrm{ACZ}$ is justified by the persistent reducing conditions created by the presence of $\mathrm{H}_{2}$ and by the non-complete conversion of $\mathrm{CO}$ and $\mathrm{CH}_{4}$. Conversely, the lower $\mathrm{CH}_{4}$ conversion values obtained at $500^{\circ} \mathrm{C}$ at $\lambda$ values of 0.97 and 1.01 after the high temperature segment reflect a negative effect of the presence of reduced Pd on activity and the difficult re-oxidation under these conditions [19]. Very similar behaviour in terms of the oxidation state of Pd was observed for Pd/A. This measurement was performed only in the case of natural gas operation. The initial 
oxidized state of $\mathrm{Pd}$ vanished between 300 and $350^{\circ} \mathrm{C}$ and was not recovered in the whole experiment similarly to $\mathrm{Pd} / \mathrm{ACZ}$, as indicated in Figure 4a. Further, Figure $4 \mathrm{~b}$ shows the FT-EXAFS spectra obtained in situ before and after subjecting Pd/ACZ to two consecutive heating-cooling cycles under steady state stoichiometric conditions up to $850^{\circ} \mathrm{C}$ [21]. As mentioned above, the fresh catalyst exhibits 1 st and 2 nd coordination shells of PdO indicating that Pd is fully oxidized. After use, the appearance of strong and well defined peak corresponding to the Pd-Pd first coordination shell at ca. $2.5 \AA$ indicates that a considerable fraction of Pd is metallic and coexists with a fraction of PdO. Therefore, under the present experimental conditions ceria-zirconia is not able to buffer the reducing conditions likely as a consequence of the length of the rich periods. Nevertheless, the persistence of the metallic character of Pd confirms observations on three-way catalysts aged under real driving conditions by XPS indicating that metallic Pd is a major species as a consequence of prolonged used [4].

It is of interest to compare the conversion profiles of $\mathrm{CH}_{4}$ and $\mathrm{C}_{3} \mathrm{H}_{6}$ during the heatingcooling segments and to relate them to the oxidation state of the catalyst obtained from the XANES spectra. $\mathrm{CH}_{4}$ conversion is already high at $500^{\circ} \mathrm{C}$ under rich conditions and reaches ca. $100 \%$ at $750^{\circ} \mathrm{C}$ (Figure 5). During cooling to $500^{\circ} \mathrm{C}$ at the lean end of the stoichiometric $\lambda$ window, conversion substantially follows the same profile as during heating with a shallow conversion gain between 550 and $700^{\circ} \mathrm{C}$. On the contrary, $\mathrm{C}_{3} \mathrm{H}_{6}$ conversion slightly improves during heating; a significant hysteresis is observed between 650 and $500^{\circ} \mathrm{C}$ during cooling that is expected from $\lambda$ sweep experiments, where hydrocarbon conversion is better under lean conditions than under rich conditions at a 
given temperature. Figure 5 demonstrates that $\mathrm{CH}_{4}$ slip can be expected in the temperature range explored in this work from operation of natural gas engines.

It is also reasonable that exposure for long time, longer than the real high frequency lambda oscillations, under rich conditions and to temperature as high as $900^{\circ} \mathrm{C}$ causes $\mathrm{Pd}$ particle growth. We had observed that this occurs under lean conditions [18]. Given the well developed signal of the Pd-Pd coordination shell, the FT-EXAFS of Figure 4b confirm that particle growth has occurred also for $\mathrm{Pd} / \mathrm{ACZ}$ after repeated reaction cycles under stoichiometric conditions. However, these structural changes did not affect the light-off characteristics for methane oxidation [21], in agreement with the observation that particle size was not a crucial parameter in determining the activity of a series of differently loaded $\mathrm{Pd} / \mathrm{Al}_{2} \mathrm{O}_{3}$ catalyst [25]. Therefore, though particle growth may have occurred in the experiments of this work, it should have occurred in a comparable manner in the case of natural gas and gasoline operation because of the identical treatment the two catalysts have been subjected to. Hence, we do not interpret the different behaviour of $\mathrm{Pd}$ in $\mathrm{Pd} / \mathrm{ACZ}$ with respect to oxidation of $\mathrm{CH}_{4}$ and $\mathrm{C}_{3} \mathrm{H}_{6}$ as being affected by $\mathrm{Pd}$ sintering. We consider that the different behavior observed in the heating-cooling segments of the cycle is determined by the different reactivity of $\mathrm{CH}_{4}$ and $\mathrm{C}_{3} \mathrm{H}_{6}$ and by the different influence of the state of Pd on their reactivity [26]. The XANES data show that under these conditions Pd remains predominantly in the reduced state. In the case of $\mathrm{CH}_{4}$, the oxidation activity of $\mathrm{Pd}$ is strongly coupled to the thermodynamic PdO-Pd equilibrium [27]. Reduction of $\mathrm{PdO}$ at high temperature $\left(>750^{\circ} \mathrm{C}\right)$ causes a reduction of oxidation activity in the cooling segment, metallic Pd being likely active at these temperatures [19]. Activity drop is typically observed also under lean burn conditions [2, 
19]. Therefore, cooling under lean conditions does not improve catalytic activity because the activity is dictated mainly by the reduced state of Pd rather than by changes in oxygen concentration in the feed. The fact that no substantial difference of activity is observed between heating (rich end of $\lambda$-window) and cooling (lean end) segments reveals that reduced Pd is not very efficient. This point is still source of debate and recently data have been reported that were interpreted by considering metallic Pd as the active phase [28]. Also, we have shown on the same $\mathrm{Pd} / \mathrm{ACZ}$ catalyst used in this work that though oxidized Pd may be responsible for activity on a fresh catalyst, a mixed $\mathrm{PdO} / \mathrm{Pd}$ phase needs to be considered at work on the used catalyst, as also shown in Figure 4b [21]. Though the present experimental conditions are static rather than real $\lambda$ oscillations, the initial oxidized state of Pd cannot be recovered even under periodic feedstock fluctuations at $500^{\circ} \mathrm{C}$ [29]. Moreover, full conversion is obtained only above $750^{\circ} \mathrm{C}$ (Figure 5) contrary to measurements conducted on oxidized samples under lean conditions [19]. Therefore, the $\mathrm{CH}_{4}$ emissions observed in real transient cycles and with $\lambda>1[5-7]$ could be partly ascribed to the effect of the oxidation state of Pd thus pointing to lower $\mathrm{CH}_{4}$ oxidation activity of extensively reduced catalysts. This issue still deserves a more systematic study. The debate on the nature of the active sites for $\mathrm{CH}_{4}$ oxidation, e.g. the role played by metallic $\mathrm{Pd}$ or $\mathrm{PdO}$, and the observation of predominantly metallic Pd obtained from this work suggest that advanced structural probes are required to be able to assess the effective role of the species present on a working catalyst. This study shows that under the applied reaction conditions transmission XANES detects predominantly metallic Pd. However, X-ray absorption spectroscopy is not able to capture a surface re-oxidation when for example changing from rich to lean conditions 
because the method is sensitive to the bulk structure. Therefore, it cannot be excluded that under these experimental conditions surface re-oxidation occurs or that the reduction observed above $300^{\circ} \mathrm{C}$ is not complete. A number of works have described the structure and the role of different Pd oxide layers or adsorbed oxygen for methane oxidation [3032]. These species would not be detected under the present experimental conditions because of the nature of XANES. We consider that working under pulsed conditions is a better approach to obtain information on the active palladium species because even for a bulk sensitive technique such as XANES it becomes possible to extract information from surface processes $[10,13,29,33]$.

In the case of $\mathrm{C}_{3} \mathrm{H}_{6}$ taken as model hydrocarbon for gasoline, the reduced state of Pd does not appear to play such a critical role as in the case of $\mathrm{CH}_{4}$ and the increase of oxygen concentration in the feed causes the expected increase of oxidation activity.

\section{Conclusions}

We have shown that the oxidation state of Pd in a Pd-only three-way catalyst strongly influences hydrocarbon oxidation activity under simulated operation conditions. $\mathrm{CH}_{4}$ abatement is mainly influenced by the reduced state of Pd. On the contrary, $\mathrm{C}_{3} \mathrm{H}_{6}$ oxidation activity is not affected by the reduced state of Pd and largely depends on the oxygen concentration of the feed. Although not conclusive on the role played by adsorbed oxygen and surface re-oxidation that can occur during operation under faster oscillatory conditions, the observed effects could contribute to rationalize observations on real catalytic converters. 


\section{Acknowledgments}

The authors kindly acknowledge Empa for financial support, Hasylab at DESY for beam time allocation, Umicore for kindly providing the catalyst sample and Dr. P. Hofer for stimulating discussions. The research leading to these results has received funding from the European Community's Seventh Framework Programme (FP7/2007-2013) under grant agreement $\mathrm{n}^{\circ} 312284$.

\section{References}

[1] P. Gelin, M. Primet, Appl. Catal. B 39 (2002) 1.

[2] R.J. Farrauto, M.C. Hobson, T. Kennelly, E.M. Waterman, Appl. Catal. A 81 (1992) 227.

[3] R. Burch, F.J. Urbano, Appl. Catal. A 124 (1995) 121.

[4] A. Winkler, P. Dimopoulos, R. Hauert, C. Bach, Appl. Catal. B: Environmental 84 (2008) 162.

[5] D.N. Tsinoglou, P. Dimopoulos-Eggenschwiler, T. Thurnheer, P. Hofer, Proc. IMechE Part D: J. Automobile Eng. 223 (2009) 819.

[6] S. Subramanian, R.J. Kudla, M.S. Chattha, Ind. Eng. Chem. res. 31 (1992) 2460.

[7] F. Klingstedt, A.K.Neyestanaki, R. Byggningsbacka, L.E. Lindfors, M. Lundén, M. Petersson, P. Tengström, T. Ollonqvist, J. Väyrynen, Appl. Catal. A 209 (2001) 301.

[8] M. Salaün, A. Kouakou, S. DaCosta, P. DaCosta, Appl. Catal. B 88 (2009) 386.

[9] V. Pitchon, C. Howitt, F. Maire, D. Bazin, P. Bernhardt, G. Maire, Nucl. Instr. and Meth. in Phys. Res. B 97 (1995) 33.

[10] P.A. Carlsson, E. Fridell, M. Skoglundh, Catal. Lett. 115 (2007) 1.

[11] J.D. Grunwaldt, N. van Vegten, A. Baiker, Chem. Commun. (2007) 4635.

[12] M.A. Newton, C. Belver-Coldeira, A. Martinez-Arias, M. Fernandez-Garcia, Nature Mater. 6 (2007) 528.

[13] D. Ferri, M. Santosh Kumar, R. Wirz, A. Eyssler, O. Korsak, P. Hug, A. Weidenkaff, M.A. Newton, PCCP 12 (2010) 5634. 
[14] A. Iglesias-Juez, A. Martinez-Arias, M.A. Newton, S.G. Fiddy, M. FernandezGarcia, Chem. Commun. (2005) 4092.

[15] S.R. Bare, T. Ressler, Adv. Catal. 52 (2009) 339.

[16] R. Burch, F.J. Urbano, P.K. Loader, Appl. Catal. A 123 (1995) 173.

[17] L. Persson, L.D. Pfefferle, W. Schwartz, A. Ersson, S.G. Järas, Appl. Catal. B 74 (2007) 242.

[18] M. Skoglundh, P. Thormählen, E. Fridell, F. Hajbolouri, E. Jobson, Chem. Eng. Sci. 54 (1999) 4559.

[19] M. Santhosh Kumar, M.H. Aguirre, A. Weidenkaff, D. Ferri, J. Phys. Chem. C 114 (2010) 9439.

[20] M. Santhosh Kumar, O. Korsak, L. Bocher, D. Logvinovich, P. Hug, A. Weidenkaff, D. Ferri, Top. Catal. 54 (2011) 1213.

[21] M. Santhosh Kumar, G.L. Chiarello, Y. Lu, A. Weidenkaff, D. Ferri, Topics Catal. doi: 10.1007/s11244-013-9960-1.

[22] T. Ressler, J. Synchrotron Rad. 5 (1998) 118.

[23] Commission Regulation (EC) No 692/2008 of 18 July 2008 implementing and amending Regulation (EC) No 715/2007 of the European Parliament and of the Council on type-approval of motor vehicles with respect to emissions from light passenger and commercial vehicles (Euro 5 and Euro 6) and on access to vehicle repair and maintenance information.

[24] M. Santhosh Kumar, E.H. Otal, M.H. Aguirre, A. Winkler, A. Ulrich, D. Rentsch, A. Weidenkaff, D. Ferri, Catal. Today 184 (2012) 237.

[25] P. Castellazzi, G. Groppi, P. Forzatti, A. Baylet, P. Marecot, D. Duprez, Catal. Today 155 (2010) 18.

[26] T. Maillet, C. Solleau, J. Barbier, D. Duprez, Appl. Catal. B 14 (1997) 85.

[27] J.G. McCarty, Catal. Today 26 (1995) 283.

[28] J.R. Theis, R.W. McCabe, Catal. Today 184 (2012) 262.

[29] A. Eyssler, E. Kleymenov, A. Kupferschmid, M. Nachtegaal, M. Santhosh Kumar, P. Hug, A. Weidenkaff, D. Ferri, J. Phys. Chem. C 115 (2011) 1231. 
[30] H. Gabasch, K. Hayek, B. Klötzer, W. Unterberger, E. Kleymenov, D. Teschner, S. Zafeiratos, M. Hävecker, A. Knop-Gericke, R. Schlögl, B. Aszalos-Kiss, D. Zemlyanov, J. Phys. Chem. C 111 (2007) 7957.

[31] K.A. Kacprzak, I. Czekaj, J. Mantzaras, PCCP 14 (2012) 10243.

[32] A. Hellman, A. resta, N.M. Martin, J. Gustafson, A. Trinchero, P.A. Carlsson, O.

Balmes, R. Felici, R. vanRijn, J.W.M. Frenken, J.N. Andersen, E. Lundgren, H. Grönbeck, J. Phys. Chem. Lett. 3 (2012) 678.

[33] C.F.J. König, J.A. van Bokhoven, T.J. Schildhauer, M. Nachtegaal, J. Phys. Chem. C 116 (2012) 19857. 


\section{Figures}

Figure 1. Total hydrocarbon and $\mathrm{NO}_{\mathrm{x}}$ conversion efficiency of a natural gas driven midsize passenger car during a Common Artemis Driving Cycle (CADC). Lambda $(\lambda)$ does not have any influence on the observed changes of pollutants conversion. CADC is a highly transient driving cycle with urban, extra-urban and motorway segments. $\lambda$ is the raw electric signal.

Figure 2. MS profiles as a function of catalyst temperature during simulated cycle of (a) natural gas and (b) gasoline operation. During the measurement $\mathrm{m} / \mathrm{z}$ values of $2\left(\mathrm{H}_{2}\right), 4$ (He), $15\left(\mathrm{CH}_{4}\right), 18\left(\mathrm{H}_{2} \mathrm{O}\right), 28\left(\mathrm{CO}, \mathrm{N}_{2}\right), 32\left(\mathrm{O}_{2}\right)$ and $44\left(\mathrm{CO}_{2}\right)$ were followed. The $\lambda$ values are indicated in the bottom panel. Heating-cooling rates were of $10^{\circ} \mathrm{C} / \mathrm{min}$.

Figure 3. Operando XANES spectra at the $\mathrm{Pd} \mathrm{K}$-edge recorded on $\mathrm{Pd} / \mathrm{ACZ}$ during the simulated driving cycle of (a) natural gas and (b) gasoline operation. The bottom spectrum in each panel corresponds to room temperature in $\lambda=0.97$. Values in brackets indicate the $\lambda$ value.

Figure 4. (a) Operando XANES spectra at the Pd K-edge recorded on $\mathrm{Pd} / \mathrm{A}$ during the simulated driving cycle of natural gas operation. The bottom spectrum corresponds to room temperature in $\lambda=0.97$. Values in brackets indicate the $\lambda$ value. (b) FT-EXAFS data obtained in situ on $\mathrm{Pd} / \mathrm{ACZ}$ before (blue line) and after (red line) two consecutive heating-cooling cycles under stoichiometric conditions. The spectrum of the reference $\mathrm{Pd}$ foil is shown for clarity (black line).

Figure 5. Methane and propene conversion profiles during the heating-cooling segments $500^{\circ} \mathrm{C} \rightarrow 900^{\circ} \mathrm{C}(\lambda=0.97)$ and $900^{\circ} \mathrm{C} \rightarrow 500^{\circ} \mathrm{C}(\lambda=1.01)$ of Figure 2. 


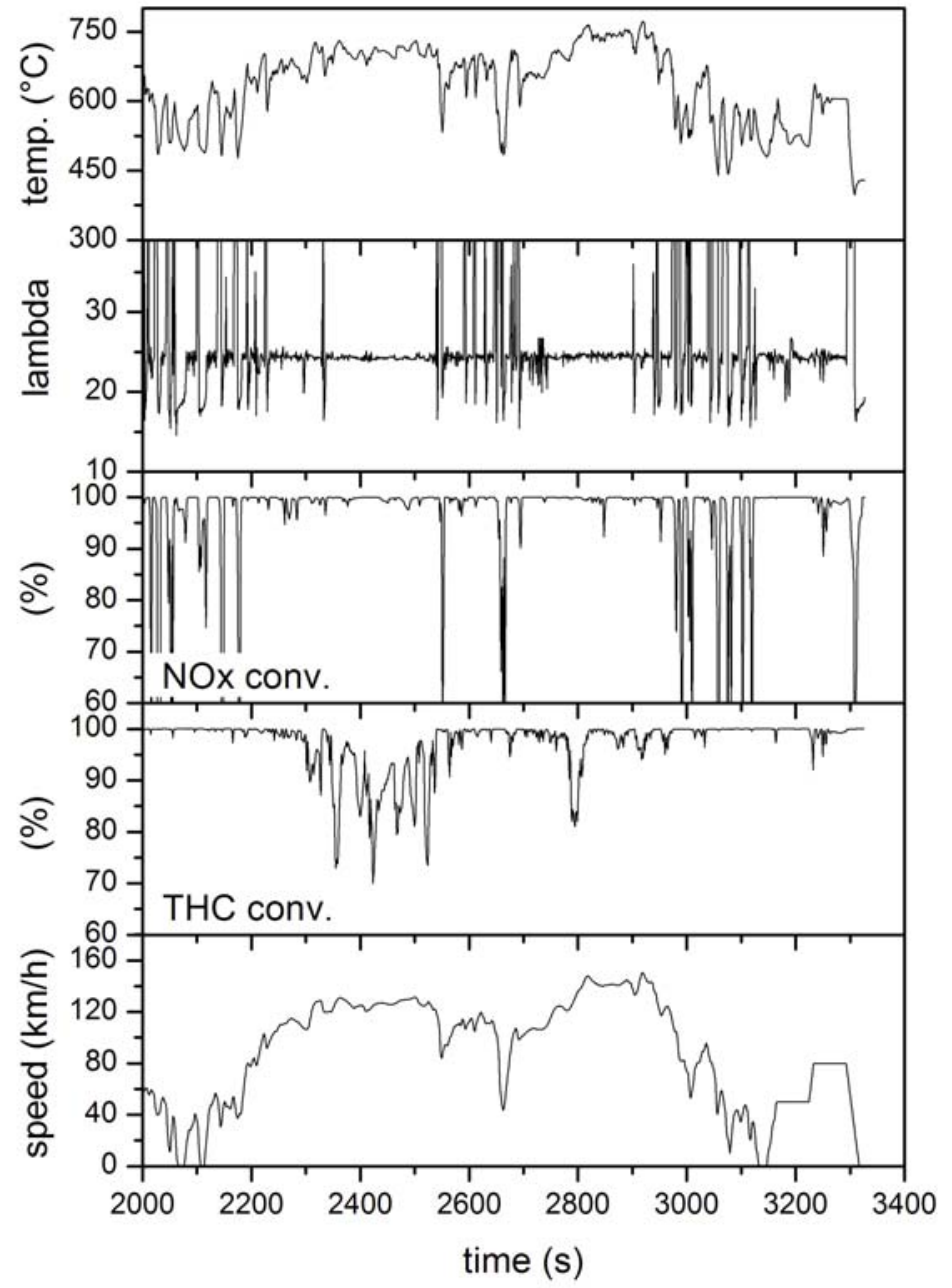

Figure 1 

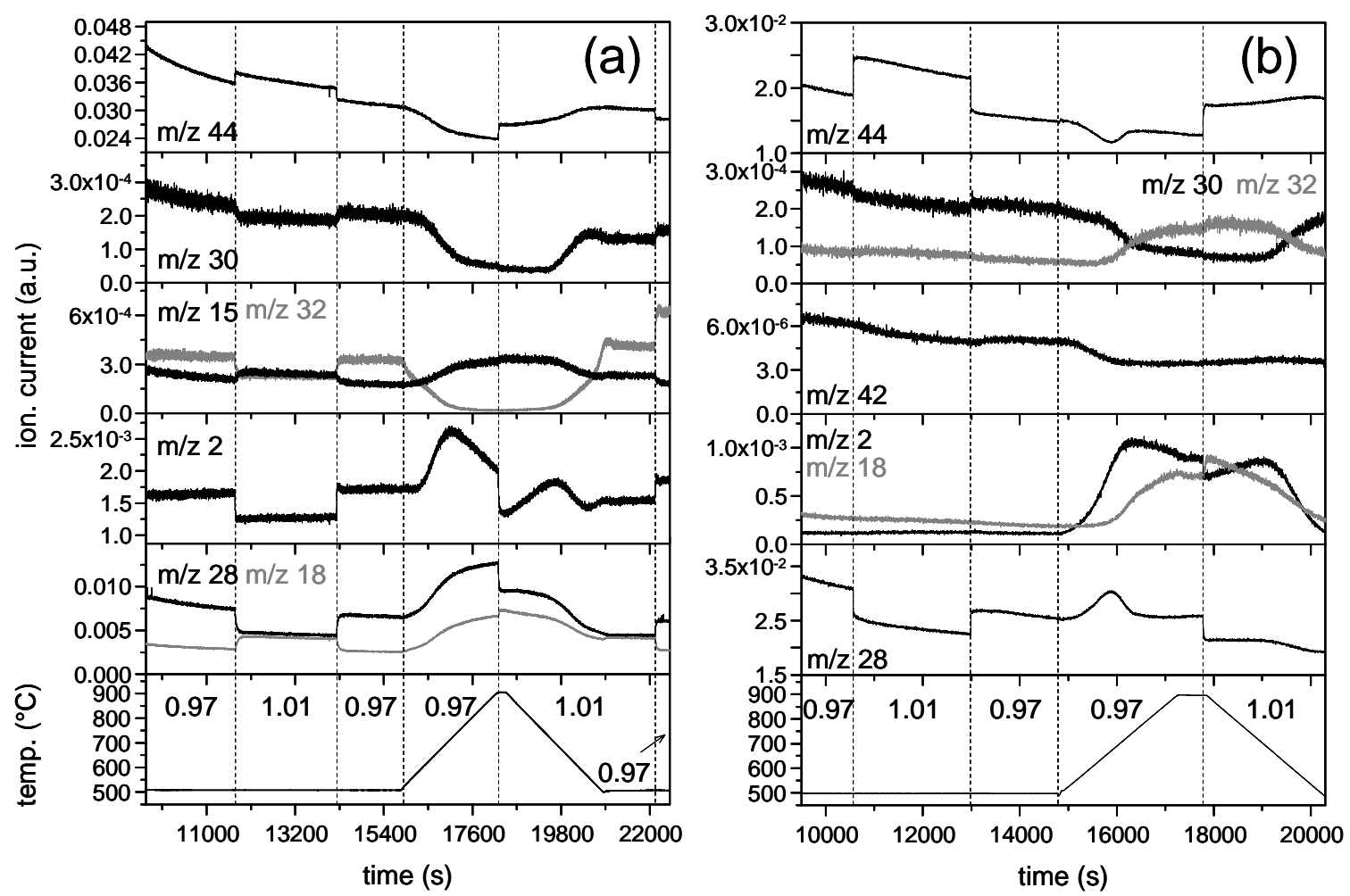

Figure 2 


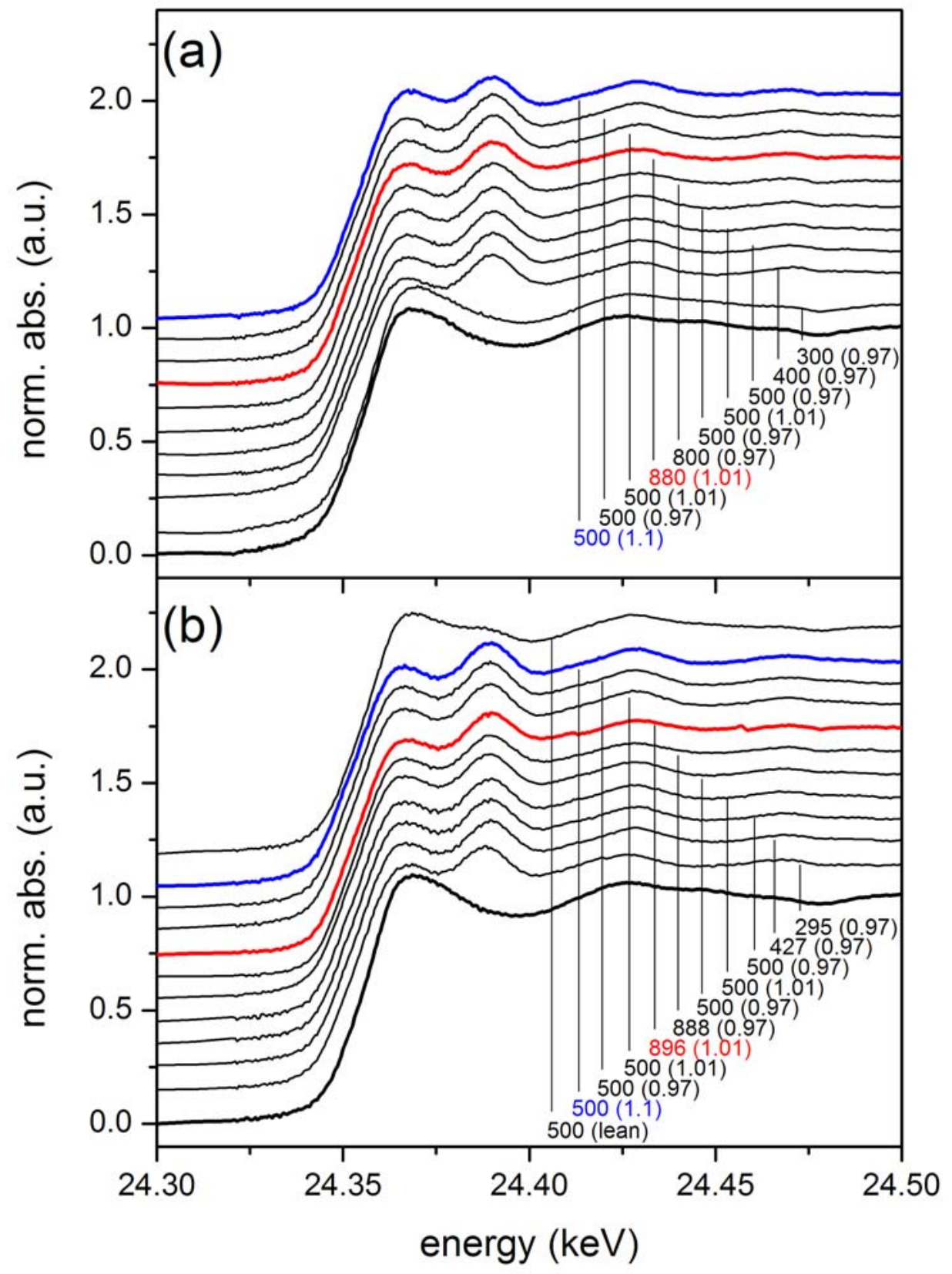

Figure 3 

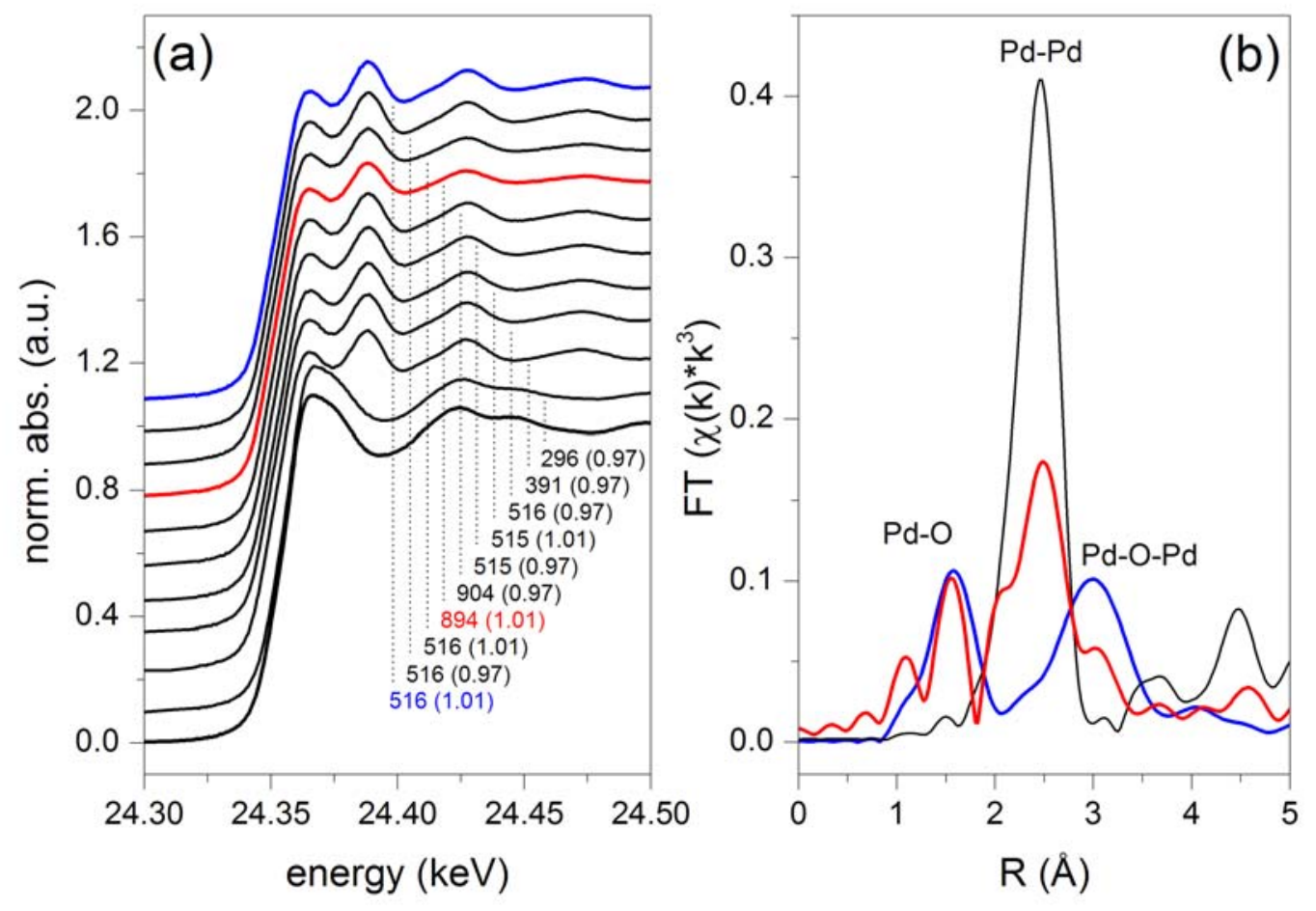

Figure 4 


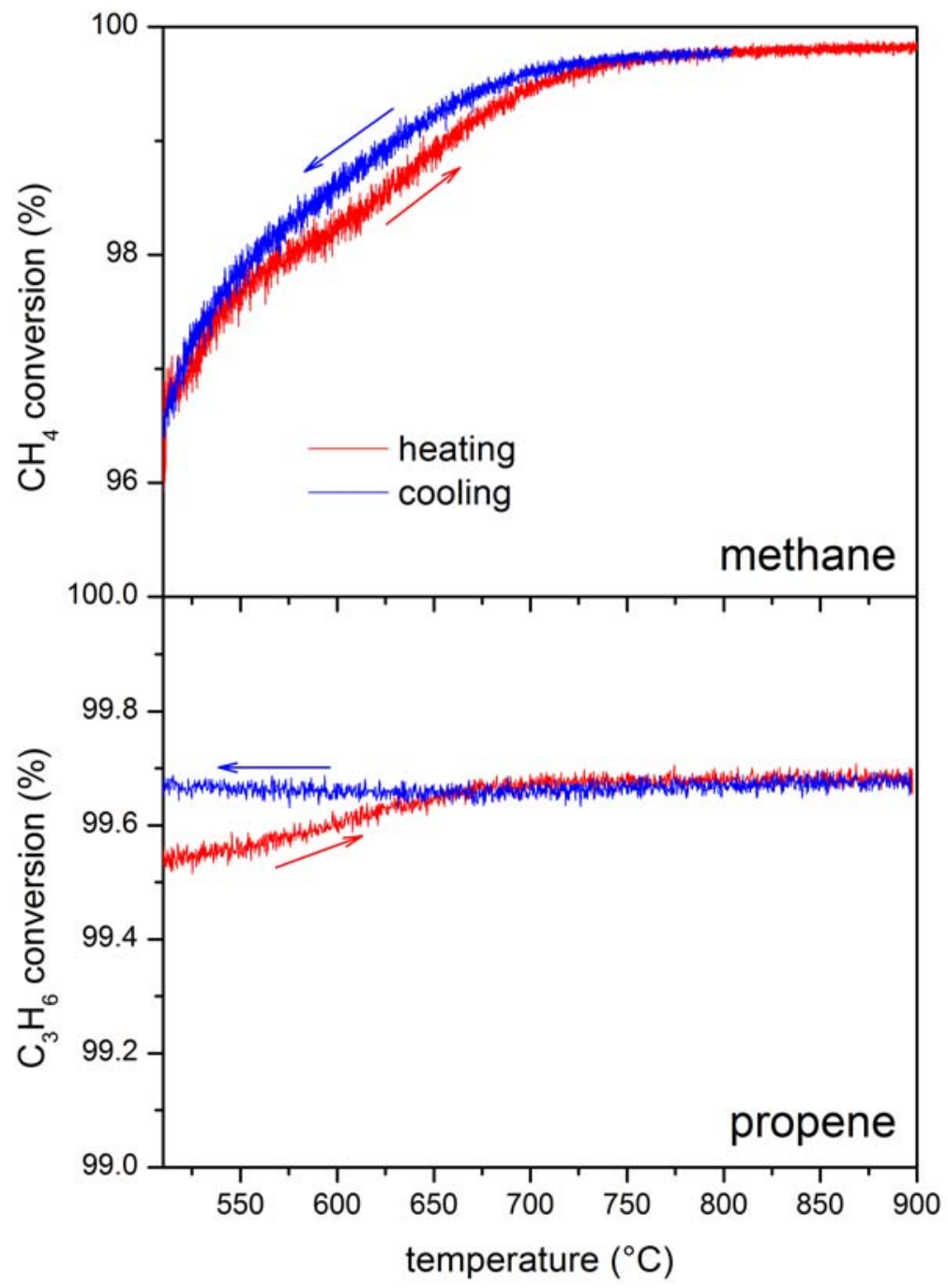

Figure 5 
Graphical abstract

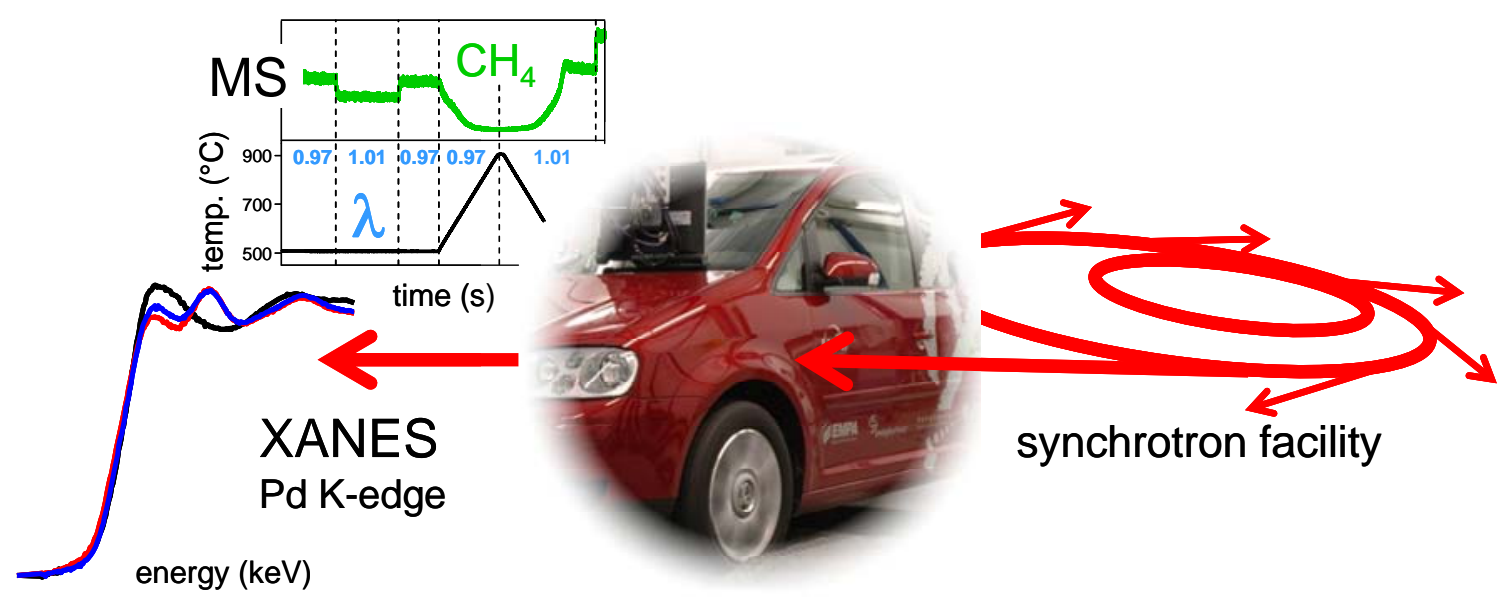

